\title{
カーボン充填カラム/安息香酸系移動相を用いるイオン クロマトグラフィーによる食品中の有機酸の定量
}

\author{
吉川 賢治 ${ }^{\circledR 1}$, 岡村 美穂 $^{1}$, 井口 美紀 ${ }^{1}$, 櫻川 昭雄 ${ }^{1}$
}

\section{Ion Chromatographic Determination of Organic Acids in Food Samples \\ Using Permanent Coating Graphite Carbon Column and \\ Mobile Phase with Benzoate}

\author{
Kenji Yoshikawa ${ }^{1}$, Miho Okamura ${ }^{1}$, Miki InOKuchi ${ }^{1}$ and Akio Sakuragawa ${ }^{1}$ \\ ${ }^{1}$ Department of Materials and Applied Chemistry, College of Science and Technology, Nihon University, 1 - 8- \\ 14, Kanda-Surugadai, Chiyoda-ku, Tokyo $101-8308$
}

(Received 11 July 2005, Accepted 27 September 2005)

\begin{abstract}
From the viewpoint of a graphite carbon column with excellent durability, it was applied to the ion chromatography (IC) of several organic acids. The carbon column was permanently coated with the cetyltrimethylammonium ion, and the elution behaviors of several organic acids (acetic acid, lactic acid, succinic acid, malic acid, tartaric acid, citric acid) and inorganic anions $\left(\mathrm{Cl}^{-}\right.$, $\mathrm{NO}_{2}{ }^{-}, \mathrm{NO}_{3}{ }^{-}, \mathrm{SO}_{4}{ }^{2-}$ ) were examined according to an ion chromatography that combined conductivity detector using a mobile phase of the benzoic acid system, when an ion-exchange ability was given to the graphite carbon column. Tartaric acid and citric acid, etc. with large valency showed tendency to which the width of each peak extended and the retention time increased. However it was possible to separate excellently for the analytes detected within ten minutes. The calibration curves obtained from the peak areas for the organic acids and inorganic anions were linear, with good correlation coefficients of 0.999 . The relative standard deviations (RSD) of the peak areas were between 0.4 and 1.0 for six repeated measurements. The developed method was then applied to the determination of organic acids in several food samples.
\end{abstract}

Keywords : graphite carbon column; organic acids; benzoic acid-tris aminomethane; ion chromatography; vinegar samples.

\section{1 緒言}

カーボン充填剤は機械的強度が大きく, 化学的安定性に も優れ, 理論的に無極性, 不活性であるといった特性があ $ろ^{1) 2)}$. また, 液体クロマトグラフィー用充填郕としても 注目され, 芳香族多環式化合物 ${ }^{3) 4)}$, 食品中の成分 ${ }^{5)}$ 等を分 析対象として検討されている。

近年では, 目的に応じたイオン相互作用試薬を組み合わ せてイオンクロマトグラフィー（IC）に適用した報告例 も見られ, その中にはあらかじめ移動相にイオン対試薬を

${ }^{1}$ 日本大学理工学部物質応用化学科：101-8308 東京都千代田区 神田駿河台 1-8-14
添加したダイナミックコーティング法 ${ }^{4) 6)}$, と充填剂表面 にイオン交換体として第四級アンモニウム塩をコーティン グするパーマネントコーティング法7゙がある.しかし，こ れらのカーボン充填剤の優れた特性にもかかわらず，あま り普及していないのが現状である.

著者らは，既にサリチル酸系緩衝溶液を移動相として， あらかじめ第四級アンモニウム塩であるセチルトリメチル アンモニウム（CTMA）イオンをコーティングさせたカラ ムを固定相に用いて有機酸の定量を試みた ${ }^{8)}$. 各イオンは 15 分程度で測定できるものの, リンゴ酸, 塩化物及び亜 硝酸イオンの分離が困難であった.

そこで本研究では同一カラムを固定相に, 安息香酸及び 
Table 1 Operating conditions for some organic acids

\begin{tabular}{ll}
\hline Column & Carbon IC BI-01 \\
& $(4.6 \mathrm{~mm}$ i.d. $\times 100 \mathrm{~mm}$, Bio Tech Research) \\
& $2.0 \mathrm{mM}$ benzoic acid $\quad(\mathrm{pH} 4.4)$ \\
Mobile phase & $-1.2 \mathrm{mM}$ tris aminomethane \\
& $(2-$-amino-hydroxymethyl-1,3-propanediol $)$ \\
& $1.0 \mathrm{ml} / \mathrm{min}$ \\
Flow rate & $40^{\circ} \mathrm{C}$ \\
Column temperature & $100 \mu \mathrm{l}$ \\
Injection volume & Conductivity \\
Detection & \\
\hline
\end{tabular}

2-アミノ-2-ヒドロキシメチル-1,3-プロパンジオール（トリ スアミノメタン）混合溶液を移動相に用い，電気伝導度検 出器を組み合わせた IC により，6 種有機酸（酢酸, 乳酸, コハク酸, リンゴ酸, 酒石酸及びクエン酸）と 4 種無機 陰イオン（塩化物, 亜硝酸, 硝酸及び硫酸イオン）の溶離 挙動を検討し, サリチル酸系移動相では分析が困難であっ たリンゴ酸・塩化物及び亜硝酸イオンの分離を可能にする とともに，食品中の有機酸の定量に応用したところ，良好 な結果が得られたので報告する.

\section{2 実験}

\section{$\mathbf{2} \cdot 1$ 装置及び測定条件}

装置は先に報告したものと同様であり ${ }^{8)}$ ，東亜 DKK 製 5000 型シリーズ，システムインスツルメンツ製 Chomatocorder 12 型によりデー夕処理を行った。分離カラムには バイオテックリサーチ製 Carbon IC BI-01（4.6 mm i.d.× $100 \mathrm{~mm}$ ，粒子径平均 $3 \mu \mathrm{m}$, 炭素含量 $99.5 \%$ 以上）を用 いた。 その測定条件を Table 1 に示す.

食品試料は孔径 $0.45 \mu \mathrm{m}$ のクロマトディスクで沪過し, 適宜水で希釈した後， $100 \mu \mathrm{l}$ を ICに注入した。

\section{$2 \cdot 2$ 試 薬}

移動相には安息香酸（和光純薬製特級 $99.5 \%$ ) 及び卜 リスアミノメタン（和光純薬製特級 $99.0 \%$ ）を混合溶液 として用いた，有機酸及び無機陰イオンの標準溶液は，既 報 $^{8)}$ と同様に小宗化学製特級，和光純薬製特級を用いて調 製した。また，硫酸イオンは硫酸ナトリウム（小宗化学製 1 級 99.0\%）を用いて調製した。 カラムの洗浄液にはアセ トニトリル（関東化学製特級 $99.8 \%$ ）を用い, コーティ ング試薬には塩化セチルトリメチルアンモニウム（CTMA$\mathrm{Cl}$ ：和光純薬製特級 $95.0 \%$ ）を用いた。

\section{$2 \cdot 3$ カラムへのコーティング方法}

カラムの洗浄操作として，アセトニトリル $50 \%$ 及び $100 \%$ 溶液を流量 $0.8 \mathrm{ml} / \mathrm{min}$ で各 1 時間程度送液した後, 純水で約 1 時間洗浄した. 次にコーティング操作として, 2 mM CTMA-Cl を流量 $0.8 \mathrm{ml} / \mathrm{min}$ で 2 時間送液し, その 後, 純水で 2 時間洗浄したものをパーマネントコーティ
ングカーボン充填カラムとして分析に使用した。また，こ のパーマネントコーティングカラムは 3 か月程度は安定 して使用可能である.

3 結果及び考察

$3 \cdot 1$ カラムコーティングのメカニズム

パーマネントコーティング法は，コーティング剤の疎水 性部分である直鎖アルキル基がカーボン表面に保持され， 移動相に面したその極性部分がイオン交換体として作用 し，イオンを分離するものと考えられる．分離モードは主 にイオン交換であるが，固定相自身の疎水性相互作用や分 配相互作用も関与していると考えられる。

また，吸収波長 $189 \mathrm{~nm}$ においてコーティング液，廃液 及び洗浄液の吸光度から CTMA の吸着量を数回の繰り返 し実験より求めた結果， $0.08 \sim 0.09 \mathrm{mmol}$ の範囲内であっ た.

\section{$3 \cdot 2$ 溶離条件の検討}

既報 ${ }^{8)}$ で困難であった 3 種イオンの分離に主眼をおきサ リチル酸系緩衝液よりも伝導度及び溶出力の低い安息香酸 系緩衝液を用いて溶離液条件の検討を行った。

まず安息香酸の濃度を $2.0 \mathrm{mM}$ に固定し，トリスアミノ メタンの濃度を変化させたときの溶離挙動を Fig. 1 に示 す。ほとんどの成分はトリスアミノメタンの濃度が増加す るにつれて保持時間が短くなる傾向を示したが，クエン酸 はそれとは逆の傾向を示した。これはトリスアミノメタン の濃度の増加により, $\mathrm{pH}$ が 4.1 から 4.7 へと増加しクエ ン酸（ $\mathrm{p} K_{\mathrm{a} 2}=4.30 ）$ の解離が進行したためと考えられる. 分析時間と各成分の分離状態を考慮し，トリスアミノメ夕 ンの濃度は $1.2 \mathrm{mM}$ とした。

同様にトリスアミノメタンの濃度を $1.2 \mathrm{mM}$ に固定し, 安息香酸の濃度を $1.5 \sim 3.5 \mathrm{mM}$ に変化させたときの溶離 挙動を調べた。全体的に保持時間が短くなる傾向を示した が，これは移動相中の $\mathrm{pH}$ が 4.7 から 4.0 へと減少するの

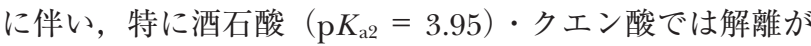
逆行し著しく保持時間が短くなったものと考えられる。安 息香酸の濃度は $2.0 \mathrm{mM}$ を最適とした。これらの保持時間 の傾向の相違は，個々の成分が持つ解離定数に起因してお 


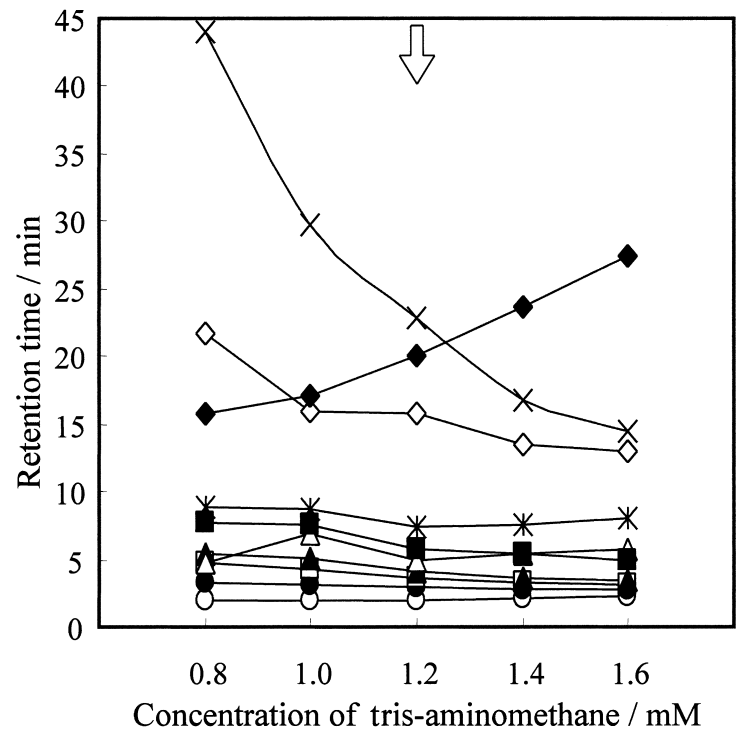

Fig. 1 Effect of Tris aminomethane concentration on retention time

Ions $\left(\mu \mathrm{g} \mathrm{ml}^{-1}\right): \bigcirc \operatorname{Acetic}(50) ; \bigcirc \operatorname{Lactic}(20) ; \triangle \mathrm{Cl}^{-}$ (5); $\boldsymbol{\Delta} \mathrm{NO}_{2}{ }^{-}$(5); $\square$ Succinic (60); $\square \mathrm{NO}_{3}{ }^{-}$(5); * Malic (50); $\diamond$ Tartaric (50); Citric (50); $\times \mathrm{SO}_{4}{ }^{2-}$ (20); Mobile phase: $2.0 \mathrm{mM}$ benzoic acid-tris aminomethane; Flow rate: $1.0 \mathrm{ml} / \mathrm{min}$; Column temperature: $40^{\circ} \mathrm{C}$

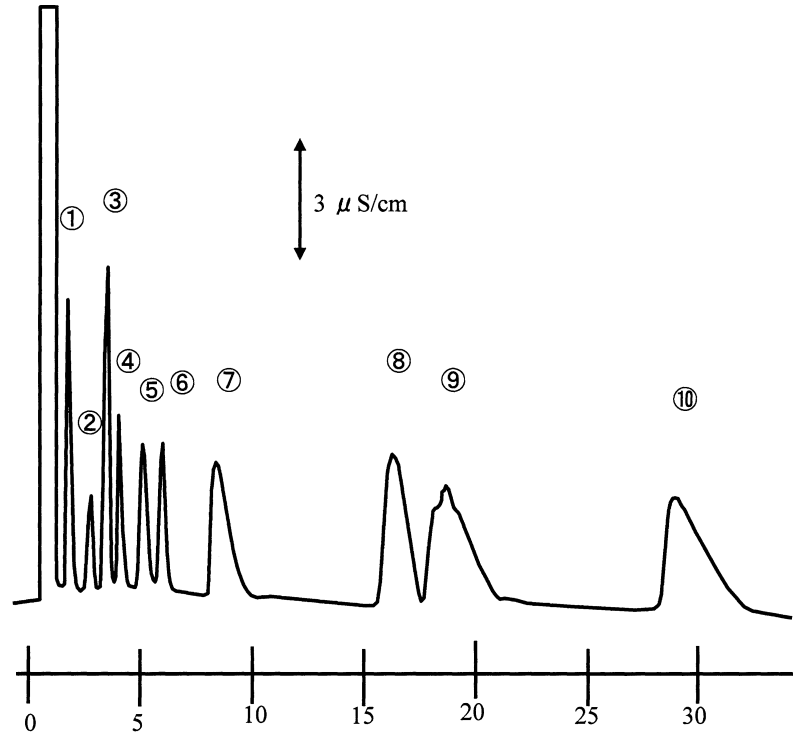

Retention time/min

Fig. 2 Chromatogram of organic acids Ions $\left(\mu \mathrm{g} \mathrm{ml}^{-1}\right)$ : (1) Acetic (50); (2) Lactic (20); (3) Cl(5); (4) $\mathrm{NO}_{2}{ }^{-}$(5); (5) Succinic (50); (6) $\mathrm{NO}_{3}{ }^{-}$(5); 7 ) Malic (50); (8) Tartaric (50); (9) Citric (50); $10 \mathrm{SO}_{4}{ }^{2-}$ (20); Mobile phase: $2.0 \mathrm{mM}$ benzoic acid- $1.2 \mathrm{mM}$ tris

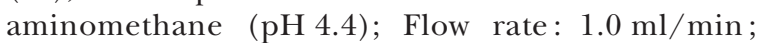
Column temperature : $40^{\circ} \mathrm{C}$

Table 2 Analytical precision of organic acids and inorganic anion

\begin{tabular}{|c|c|c|c|c|}
\hline $\begin{array}{l}\text { Organic acid } \\
\text { and } \\
\text { Inorganic anion }\end{array}$ & \multicolumn{2}{|c|}{$\begin{array}{l}\text { Reproducibility } \\
\quad\left(\operatorname{RSD}_{0} \%\right) / \\
\mu \mathrm{g} \mathrm{ml} \mathrm{m}^{-1}(n=6)\end{array}$} & $\begin{array}{l}\text { Determination limit } \\
\qquad \begin{array}{c}(S / N=10) / \\
\mu \mathrm{g} \mathrm{ml}^{-1}\end{array}\end{array}$ & $\begin{array}{c}\text { Linearity } \\
r^{2} \text { of calibration curves/ } \\
\mu_{\mathrm{g} \mathrm{ml}}^{-1}(n=5)\end{array}$ \\
\hline Acetic acid & 50 & 0.46 & 3.6 & $0.9992(10 \sim 200)$ \\
\hline Lactic acid & 50 & 0.40 & 6.9 & $0.9997(10 \sim 100)$ \\
\hline Succinic acid & 50 & 0.40 & 8.7 & $0.9999(10 \sim 200)$ \\
\hline Malic acid & 50 & 0.73 & 13.6 & $0.9990(20 \sim 120)$ \\
\hline Tartaric acid & 50 & 0.84 & 8.5 & $0.9991(30 \sim 200)$ \\
\hline Citric acid & 50 & 0.75 & 11.5 & $0.9998(40 \sim 200)$ \\
\hline $\mathrm{Cl}^{-}$ & 10 & 0.46 & 0.3 & $0.9992(1 \sim 20)$ \\
\hline $\mathrm{NO}_{2}{ }^{-}$ & 10 & 0.54 & 0.6 & $0.9993(1 \sim 20)$ \\
\hline $\mathrm{NO}_{3}{ }^{-}$ & 10 & 0.87 & 0.6 & $0.9992(1 \sim 20)$ \\
\hline
\end{tabular}

RSD : Relative standard deviation

り, 移動相の $\mathrm{pH}$ によって各成分の解離状態が左右される ためと推測される. 更には本法で用いた固定相の分離モー ドがイオン交換以外にもイオン排除や固定相自身の極性相 互作用など，分離他のモードの関与があると考えられる.

\section{$3 \cdot 3$ 有機酸及び無機陰イオンのクロマトグラム}

決定した最適条件における有機酸及び無機陰イオンのク ロマトグラムを Fig. 2 に示す。サリチル酸系移動相に比 ベて安息香酸とトリスアミノメタン水溶液の移動相は溶出 力が弱いため, 酒石酸やクエン酸など価数が大きい成分の ピークはブロード化や溶出時間が遅くなる傾向を示した. しかし，10 分以内に近接している成分に関しては良好に
分離でき，特にこれまで分離が困難であったリンゴ酸，塩 化物及び亜硝酸イオンを分離することが可能になった。よ って，目的に応じて 2 種類の移動相を使い分けることで, これまで定量が困難な成分に関して定量が可能になると考 えられる。

\section{$3 \cdot 4$ 分析精度}

定量可能な成分について，各濃度範囲におけるピーク面 積より検量線を作成した. Table 2 にその結果を示す。そ れぞれの定量範囲内の 5 点をとり，作成した検量線の相 関係数は 0.999 以上を示した。また，定量限界 $(S / N=$ 10）は有機酸の場合 $3.6 \sim 13.6$ ，無機陰イオンの場合 0.6 
Table 3 Analytical results for organic acids in food sample

\begin{tabular}{|c|c|c|c|c|c|}
\hline Sample & Organic acids & $\begin{array}{l}\text { Concentration/ } \\
\mathrm{mg} 100 \mathrm{ml}^{-1}\end{array}$ & $\mathrm{Add} / \mathrm{mg} \mathrm{l}^{-1}$ & Recovery, \% & $\operatorname{RSD}, \%(n=3)$ \\
\hline \multirow{4}{*}{$\begin{array}{l}\text { Moromi } \\
\text { vinegar }\end{array}$} & 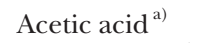 & 208 & 50 & 88 & 1.32 \\
\hline & Succinic acid ${ }^{a)}$ & 134 & 50 & 99 & 3.44 \\
\hline & Malic acid $^{\text {a) }}$ & 90 & 50 & 91 & 3.10 \\
\hline & Citric acid ${ }^{\text {a) }}$ & 547 & 30 & 95 & 0.66 \\
\hline \multirow{3}{*}{$\begin{array}{c}\text { Nutritions } \\
\text { drink }\end{array}$} & Acetic acid ${ }^{\text {b) }}$ & 11 & 50 & 91 & 2.84 \\
\hline & Malic acid $^{\text {b) }}$ & 7.5 & 50 & 100 & 0.70 \\
\hline & Citric acid ${ }^{c)}$ & 795 & 30 & 100 & 0.98 \\
\hline Cider & Acetic acid $^{\text {d) }}$ & 4600 & 50 & 92 & 0.42 \\
\hline \multirow{2}{*}{ vinegar } & Malic acid $^{\text {e) }}$ & 51.7 & 50 & 102 & 1.79 \\
\hline & 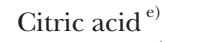 & 157 & 30 & 81 & 0.32 \\
\hline \multirow[t]{3}{*}{ Yogurt } & 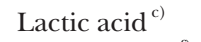 & 215 & 50 & 86 & 0.72 \\
\hline & Succinic acid $^{\mathrm{f})}$ & $<$ d.l. & - & - & - \\
\hline & Citric acid $^{\mathrm{f})}$ & 36.3 & 50 & 103 & 0.85 \\
\hline \multirow[t]{3}{*}{ Red wine } & Acetic acid $^{\mathrm{g})}$ & 35 & 50 & 92 & 2.55 \\
\hline & Succinic acid $^{\mathrm{g})}$ & 75 & 50 & 93 & 0.45 \\
\hline & Citric acid ${ }^{g)}$ & 352 & - & - & 0.48 \\
\hline
\end{tabular}

a) $1 / 32$ dil; b) $1 / 2$ dil ; c) $1 / 50$ dil ; d) $1 / 400$ dil ; e) $1 / 16$ dil ; f) $1 / 4$ dil ; g) $1 / 25$ dil ; d.1. : detection limit; RSD : Relative standard deviation

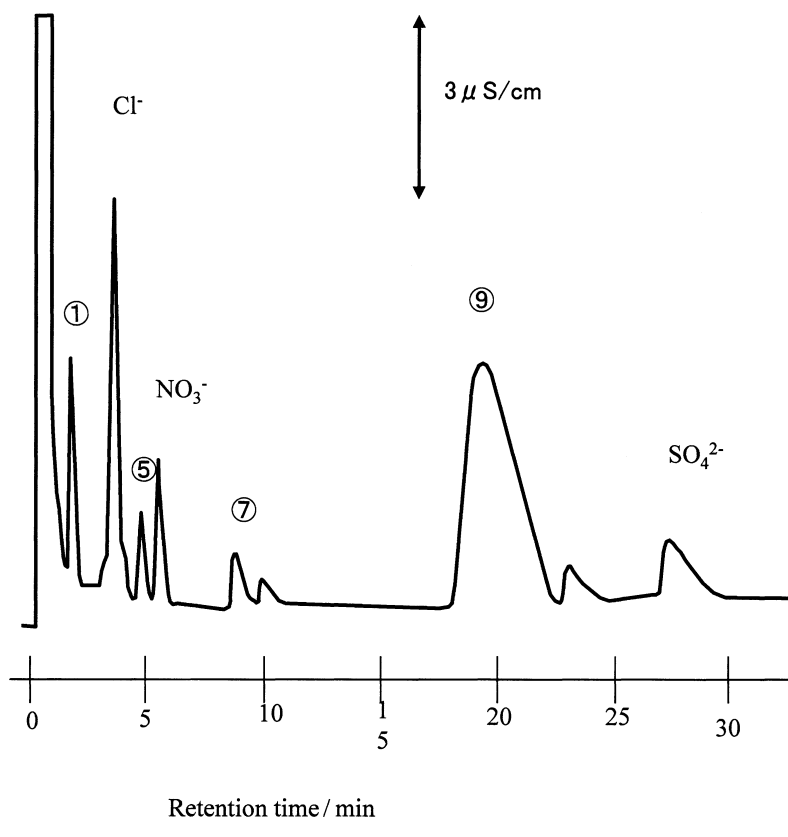

Fig. 3 Determination of organic acid in vinegar sample

Ions: (1) Acetic; (3) $\mathrm{Cl}^{-}$; (5) Succinic; (6) $\mathrm{NO}_{3}{ }^{-}$; $(7)$ Malic ; (9) Citric ; (10) $\mathrm{SO}_{4}{ }^{2-}$; Mobile phase : $2.0 \mathrm{mM}$ benzoic acid-1.2 mM tris aminomethane $(\mathrm{pH} 4.4)$; Flow rate: $1.0 \mathrm{ml} / \mathrm{min}$; Column temperature : $40^{\circ} \mathrm{C}$

$\mathrm{mg} / \mathrm{l}$ 以下であり，6 回繰り返し測定による相対標準偏差 は $1.0 \%$ 以内と良好な再現性を示したので，本法を実試料 に適用した。

\section{$3 \cdot 5$ 実試料への適用}

実試料は食酢や栄養ドリンクを用いた。琉球もろみ酢の
クロマトグラムを Fig. 3 に示す. その定量結果を含め, 他の実試料にも適用した結果を Table 3 に示す. 各実試 料については既報 ${ }^{8)}$ と同様に ODS カラムを用いて測定し たところ，許容誤差は $1.0 \%$ であった。更に本法の信頼性 を確認するため, 添加した有機酸の添加回収実験を行っ た。回収率は $100 \%$ 近い值であり，他の共存物質の影響 を受けないことが確認できた. ヨーグルトは固体 $5 \mathrm{~g}$ に水 $20 \mathrm{ml}$ を加えて 20 分間かき混ぜた後, 溶液のすべてを $2000 \mathrm{rpm}$ で遠心分離機に 20 分間かけ, 得られた上澄み液 を実試料として注入した。

\section{4 結 言}

本研究では移動相を使い分けることにより，有機酸と無 機陰イオンの同時分析が可能になることが分かった。ま た，他のマトリックスの影響を受けずに本法が実試料に適 用できることを確認した。

\section{文献}

1) J. Qiu, X. Jin: J. Chromatogr. A, 950, 81 (2002).

2) T. Hanai: J. Chromatogr. A, 989, 183 (2003).

3) J. H. Knox, B. Kaur: "High-Performance Liquid Chromatography”, p. 189 (1990), (J. Wiley \& Sons, New York)

4) J. H. Knox, Q. H. Wan: Chromatographia, 42, 83 (1996).

5) J. Rosen, K. E. Hellenas: Analyst, 127, 800 (2002).

6) T. Okamoto, A. Isozaki, H. Nagashima: J. Chromatogr. A, 800, 239 (1998).

7) H. Nagashima, T. Okamoto: J. Chromatogr. A, 855, 261 (1999).

8) 櫻川昭雄, 中根美紀: 分析化学 (Bunseki Kagaku), 53, 851 (2004). 